\title{
Promoting Food Waste Reduction at Primary Schools. A Case Study
}

\author{
Adriana Antón-Peset ${ }^{1}$, Maria-Angeles Fernandez-Zamudio ${ }^{2}$ iD and Tatiana Pina ${ }^{1, *(D)}$ \\ 1 Department of Experimental and Social Sciences Education, Universitat de València, 46022 Valencia, Spain; \\ adriana.a.peset@gmail.com \\ 2 Centro para el Desarrollo de la Agricultura Sostenible, Instituto Valenciano de Investigaciones Agrarias, \\ Moncada, 46113 Valencia, Spain; fernandez_marzam@gva.es \\ * Correspondence: tatiana.pina@uv.es
}

check for updates

Citation: Antón-Peset, A.;

Fernandez-Zamudio, M.-A.; Pina, T. Promoting Food Waste Reduction at Primary Schools. A Case Study. Sustainability 2021, 13, 600 . https://doi.org/10.3390/su13020600

Received: 16 December 2020 Accepted: 6 January 2021 Published: 10 January 2021

Publisher's Note: MDPI stays neutral with regard to jurisdictional clai$\mathrm{ms}$ in published maps and institutional affiliations.

Copyright: $(\odot 2021$ by the authors. Licensee MDPI, Basel, Switzerland. This article is an open access article distributed under the terms and conditions of the Creative Commons Attribution (CC BY) license (https:// creativecommons.org/licenses/by/ $4.0 /)$.

\begin{abstract}
Food waste (FW) has recently attracted the interest of different institutions and has been the focus of many studies due to its important environmental, social and economic impact. This paper aims to analyze whether a didactic intervention, consisting of informing teachers and pupils and involving pupils in reducing FW, could bring about changes in the level of knowledge and attitude towards FW and in the amount of FW generated during the mid-morning break and lunch at schools. This study was conducted at a public Primary School in Valencia (Spain). Subtle changes in the level of knowledge and attitude towards FW were detected in teachers and pupils after the intervention. Around $30 \%$ of FW reduction at lunch was observed in the intervention group but not in the other groups. A decrease of almost half of the average weight was observed during the mid-morning break in the rest of primary groups. The results apparently show that addressing the FW issue in classrooms can have a very positive effect on children's attitudes. As it is such a cross-cutting issue; it raises awareness about a large group of Sustainable Development Goals, and encourages these young citizens to make conscious decisions and to act responsibly.
\end{abstract}

Keywords: waste; school canteen; Sustainable Development Goals; sustainable feeding; sustainable education; responsible consumption

\section{Introduction}

In 2015 the United Nations General Assembly approved the 2030 Agenda for Sustainable Development, a global action plan to eradicate poverty, and to promote sustainable and equitable development, made up of 17 Sustainable Development Goals (SDG) and 169 targets to be met by 2030 [1]. Specifically within SDG 12 "Responsible consumption and production", target 12.3 proposes to "halve per capita global food waste at the retail and consumer levels, and reduce food losses along production and supply chains, including post-harvest losses" by 2030, which demonstrates that food waste (FW) is one of the global problems that humanity faces today [1,2]. According to a report by the Food and Agriculture Organization of the United Nations (FAO), one third of all food produced worldwide is lost or wasted [3]. This amounts to 1.3 billion tons of food every year. Only in the European Union different studies estimate that FW ranges from 88 to 89 million tons per year, which is between 173 and $179 \mathrm{~kg}$ per capita [4,5], with Spain being the seventh most wasteful country in Europe with an estimated 7.7 million tons of FW per year, the equivalent to a per capita average of $170 \mathrm{~kg}$ [4].

The direct economic cost of all annually wasted food is estimated at 577 billion euros [6]. Apart from the economic cost of food, an additional cost in resources is incurred, such as land, water, labor and transport, which is not often factored in the FW cost. Producing food that ends up being thrown away is not only an economic problem, but also a socio-environmental one. Socially speaking, with today's economic crisis, aggravated by the COVID-19 health crisis [7-9], and in a world where two billion people (25.9\% of the 
world's population) go hungry or cannot regularly access sufficient and nutritious food, are undernourished or chronically hungry [10], FW has a major ethical impact in terms of both health and social equality. In relation to the environment, FW is associated with a very large ecological footprint because it involves the waste of resources for managing FW, apart from wasted resources (water, soil, energy) invested in food production, processing and transport [11-13]. Globally, the water footprint for the total wasted food production is $250 \mathrm{~km}^{3}$ per year and the carbon footprint is estimated at 3.3 Gtons of $\mathrm{CO} 2$ equivalents, without considering greenhouse gas emissions from land use change [6].Therefore, reducing the amount of food lost and wasted is one of the most promising measures to move towards the food system's sustainability [14]. For all these reasons, FW needs to be addressed from the three sustainability dimensions: social, environmental, economic [14,15].

In developed countries, FW figures are higher at the end of the food chain $[5,16]$ as is loss of the resources associated with it [17]. Hence waste prevention is particularly relevant at the end of the food chain [18]. The post-retail consumption level includes not only households [5], but also the institutional food service sector (schools, prisons, hospitals) $[19,20]$, of which school canteens are a major source of FW. At primary schools, an average of $15 \%$ to $30 \%$ of every meal is wasted (72 $\mathrm{g}$ to $120 \mathrm{~g}$ per child per day) [21]. In Spain it is estimated that at this level, FW ranges from $40 \mathrm{~g}$ to $100 \mathrm{~g}$ per pupil per meal, which would be the equivalent to 12 million $\mathrm{kg}$ of food wasted per year only in Primary Education [22].

By focusing on the FW generated in the education context, several studies have investigated different strategies to reduce it. These include direct interventions, such as carrying out comprehensive information campaigns and awareness activities about FW with students [23,24]. Other strategies involve them explaining what they have learned to their families in an attempt to modify their food habits [23], or engaging them in FW quantification $[24,25]$. Other authors have, nevertheless, used strategies that act indirectly on students. Ozcicek-Dolekoglu and Var [26] and Soares et al. [27] organized awareness campaigns by placing informative posters about FW in canteens so that students could read them during meals to analyze if these posters had any effect on students' behavior.

Analyzing FW, making it visible, raising awareness about it and educating about it and its consequences form a fundamental strategy to combat it [28]. However, not all FW reduction interventions achieve FW reduction, as not all FW articles deal with applied interventions [29,30]. The in-depth study carried out by Reynolds et al. [29] demonstrated that when applying interventions in households, hospitality and hotels and educational establishments, the majority of current interventions achieve only a $5-20 \%$ reduction in FW after combining different methodologies. Stöckli et al. [30] suggested that despite informational interventions that aim to increase knowledge and skills being the most widely used strategy, they were relatively ineffective if not used in combination with other intervention types, such as prompts, modelling or commitments. Hebrok and Boks [31] suggested that the success of written messages, social information, awareness campaigns and online advices depends on the design intervention, and highlighted the importance of a synergy of different approaches to reduce FW.

Therefore, tackling this problem through different approaches in the school environment is a marvelous opportunity for the educational community to become aware of FW and to, thus, promote training initiatives that contribute to minimize FW by encouraging changes in eating habits towards more sustainable models that can reach many people: children, teachers, staff and families [32-34]. Food education forms part of the education program, and is being increasingly integrated into the school curriculum from a human health perspective [35,36]. However, food education should also be considered an opportunity to train pupils in civic responsibility, and for them to perceive the study of FW as a transversal concept from which different sustainability aspects can undoubtedly be addressed.

This idea is also reflected in the 2030 Agenda, which confers to education a strategic value to address the challenges that we face as a society through its SDG 4 (Quality 
Education) [37], which seeks education that facilitates the transition towards sustainability and promotes changes in both attitudes and behavior [38]. In this context, the present paper aims to: (i) explore the degree of knowledge, awareness and attitudes of pupils and teachers towards this problem with a case study; (ii) quantify the FW generated during the mid-morning breaks and lunches eaten in the school canteen of a Public Nursery and Primary Education center; (iii) check whether changes in the analyzed variables can be attributed to the educational intervention carried out in the classroom and the center. The defended hypothesis is that the level of awareness and involvement to avoid FW in pupils and teachers will increase and, therefore, the amount of FW generated by pupils during the mid-morning breaks and lunches will lower after carrying out the educational intervention.

\section{Materials and Methods}

This paper describes the FW problem framed in a specific real context, and analyzes the consequences of a small educational intervention designed to reduce it. We conducted a case study because, given the exploratory nature of this issue, our intention was to understand the process through which a didactic intervention focused on FW classrooms promotes changes in knowledge, awareness and attitudes of both pupils and teachers, and is able to grasp all its complexity by relying on different sources and data $[39,40]$. According to Yin [41], a case study "is an empirical method that investigates a contemporary phenomenon (the "case") in depth and within its real-world context, especially when the boundaries between phenomenon and context may not be clearly evident, ... ".

\subsection{Participants and Setting}

The case study was conducted in a public primary school (Nursery to year 6 of Primary Education) in the city of Valencia (Spain) from March to May 2019. This center was chosen for several reasons: (1) we were acquainted with the school's headmistress; (2) the sociocultural level of both pupils and their families was average; (3) the center's staff expressed their concern about considerable FW. The teaching staff consisted of 17 teachers, including Nursery $(n=4)$, Primary $(n=7)$ and Specialist teachers $(n=6)$. During academic year 2018-2019, 250 pupils attended the center. We followed one Primary School teacher and her class (13 boys and 12 girls aged between 9 and 10 years; year 4) while teaching one unit (six lessons) with didactic materials and activities especially developed to foster FW reduction. The research phases are summarized in Figure 1.

In order to carry out our study, the headmistress and the person in charge of the school canteen were contacted beforehand and informed of the sought objectives to involve them in performing the work and to request authorization. Both played a relevant role in involving the rest of the school community and in correctly collecting primary data in the canteen. To collect data from pupils, families were asked for informed consent. Only 14 families gave it.

\subsection{Data Collection and Evaluation Strategy}

Papargyropoulou et al. [42] emphasized the need to use quantitative, but also qualitative methods to study FW as social and motivational practices and individual behaviors cannot be analyzed by quantitative methods alone. For this reason, we decided to carry out a single-case (embedded) design because it allows the combination of qualitative and quantitative techniques to collect data [41]. Accordingly, we considered FW at schools as the main unit and the classroom where the intervention was carried out as the smallest unit in our design.

Case study evidence can come from at least six sources: documents, archival records, interviews, direct observations, participants' observations and physical artifacts [39]. Table 1 describes the instruments employed in this work to analyze pupil and teacher knowledge, awareness and attitudes, which were questionnaires for pupils and teachers, the posters and recordings used with pupils during the awareness activities and FW quantification. 
Table 1. Instruments employed to analyze pupils and teachers' knowledge, awareness and attitude.

\begin{tabular}{|c|c|c|}
\hline $\begin{array}{c}\text { Dimensions } \\
\text { Analyzed }\end{array}$ & Pupils & Teachers \\
\hline Knowledge & $\begin{array}{l}\text { Questionnaire: } \\
\text { 1- What do you understand by food } \\
\text { waste }(F W) \text { ? } \\
\text { 2-Draw what FW is for you. }\end{array}$ & $\begin{array}{l}\text { Questionnaire: } \\
\text { 1- Could you define food waste } \\
\text { (FW) in your own words? }\end{array}$ \\
\hline Awareness & $\begin{array}{l}\text { Questionnaire: } \\
\text { 3- Are you worried about throwing } \\
\text { food away? } \\
\text { 4- Why? } \\
\text { Awareness activities: } \\
\text { 1- Informative posters for the } \\
\text { canteen and playground created by } \\
\text { pupils. } \\
\text { 2- Recording pupils' presentations } \\
\text { to other pupils from the center. }\end{array}$ & $\begin{array}{l}\text { Questionnaire: } \\
\text { 2-Indicate on a scale from } 1 \text { to } 5 \\
\text { your interest in FW, where } 1 \text { is not } \\
\text { interested and } 5 \text { is very interested. } \\
\text { 3- Do you consider FW to be a } \\
\text { problem? } \\
\text { 4- Why? }\end{array}$ \\
\hline Attitude & $\begin{array}{l}\text { Questionnaire: } \\
\text { 5- Do you ever throw away part of } \\
\text { the snack you bring from home? } \\
\text { (yes, every day; only sometimes; } \\
\text { never because I eat it all; never } \\
\text { because I take any leftovers home). } \\
\text { 6- Do you ever throw away some of } \\
\text { the food you are served at lunch? } \\
\text { (yes, every day; only sometimes; } \\
\text { never because I eat it all). } \\
\text { Measuring the food wasted at } \\
\text { mid-morning break and lunch. }\end{array}$ & $\begin{array}{l}\text { Questionnaire: } \\
\text { 5- In the subjects you teach, how } \\
\text { often (never, rarely, sometimes, } \\
\text { frequently, very frequently) are the } \\
\text { following issues addressed?: } \\
\text { importance of diet, food } \\
\text { management, environmental } \\
\text { impact of food generation and } \\
\text { consumption, product labelling, FW } \\
\text { concept, unequal food distribution } \\
\text { worldwide, energy and water } \\
\text { saving, waste generation, recycling. }\end{array}$ \\
\hline
\end{tabular}

The quantification of the FW generated by pupils and the administration of questionnaires to pupils and teachers were carried out before and after the didactic intervention to detect any possible changes related to it. The two questionnaire models (pupils and teachers) were previously validated by education community members.

After the intervention, the teachers' questionnaire was slightly modified by deleting the question about the frequency with which they deal with sustainability issues in their classes because no changes were expected during such a short period of time. They were also asked if they had read an information leaflet provided by those responsible for this study, which delves into the problem and presents different ways to work on it in class and, if after doing so, they saw the feasibility of incorporating it into their teaching. They were also encouraged to put forward proposals which, from their point of view, could be useful for working on FW in the classroom.

A survey was also sent to the parents of those pupils participating in the intervention to find out if their children had presented the FW problem at home.

\subsection{Didactic Intervention}

The United Nations Organization recognizes the crucial role of education for social transformation and for achieving Sustainable Development Goals (SDG) [37,43]. For this reason, target 4.7 of SDG 4 states that by 2030, it should be ensured that "all learners acquire the knowledge and skills needed to promote sustainable development, including, among others, through education for sustainable development and sustainable lifestyles, ..." [1]. However, even though FW is extremely important globally and very common in the school context, it is not usually studied specifically at schools. This was why the intervention pursued, through active and participatory methodologies, knowledge, awareness and pupils' involvement in this problem to motivate them to recognize their role and responsibility as citizens, and to perceive themselves as drivers of change. 

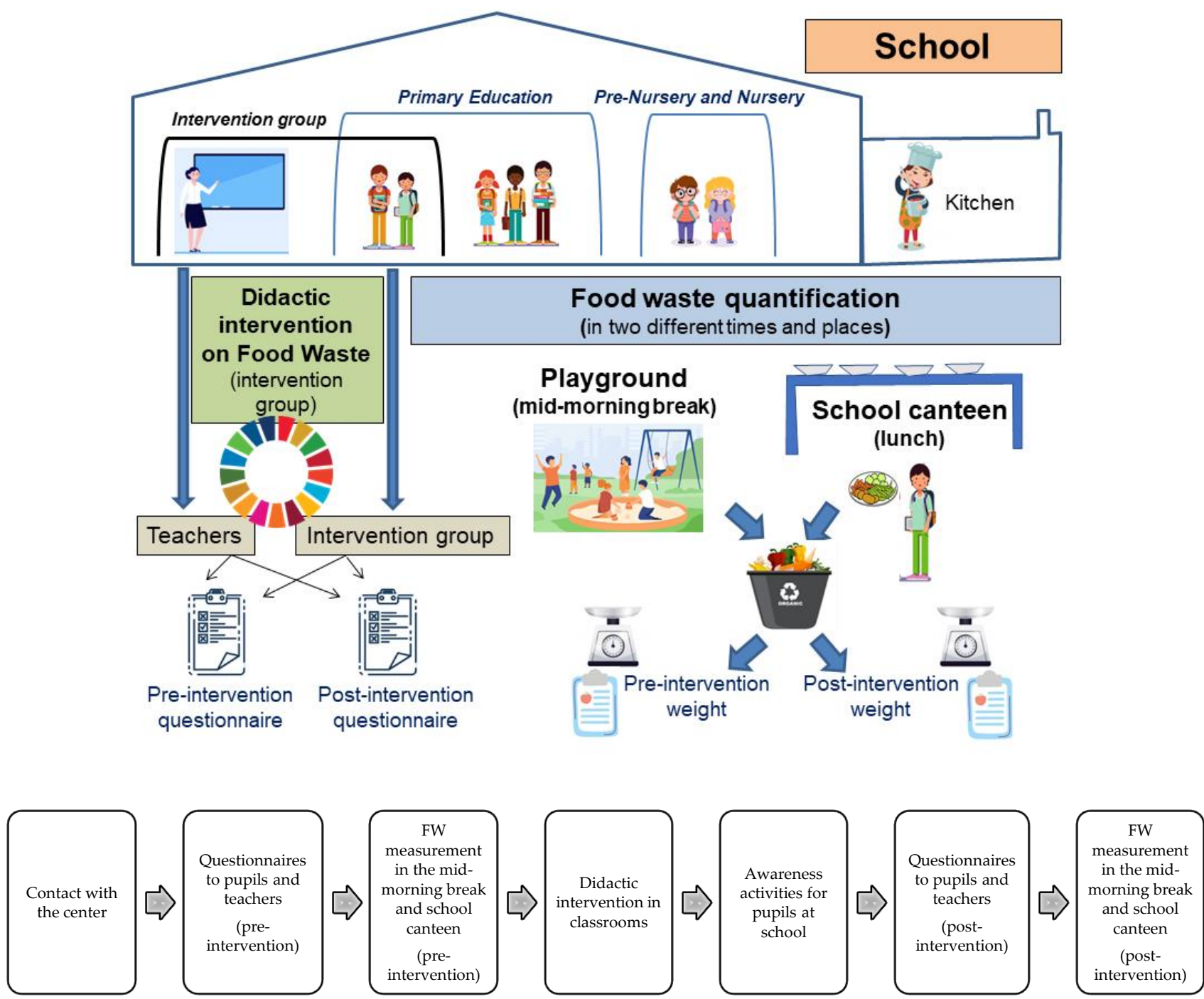

Figure 1. All of the sequences (above) and research phases (below) performed in the case study. Source: designed by the authors using images from freepik.com and un.org.

Table 2 schematically shows the intervention carried out to reduce FW at school. The intervention group was directly involved in studying FW with six 45-min teaching sessions held over 3 weeks, and 15 activities carried out. The activities are numbered according to their order of performance and classified in accordance with their typology (exploring, intervention, extrapolation or synthesis) and grouping (individual, small group, class group). Teaching sessions formed part of the Civic and Social Values subject, which deals with people's responsibility in society, their personal contribution to environmental conservation, responsible use of natural resources and responsible consumption, co-existence and social values [35]. The aim of this educational intervention was to train pupils in the FW concept and to inform them about its impact, mainly in social and environmental terms, so they could later get involved in awareness activities with their classmates in other courses to, thus, generate a cascade learning process. All pupils in the intervention group $(n=25)$ participated in the didactic intervention, except for the questionnaires, which only 14 students were authorized to answer and, of these, only ten answered both pre- and post- intervention questionnaires. However, the entire class made the drawings, designed the murals and participated in the dissemination session. 
Table 2. Activities and contents worked during each session, numbered according to their order of performance and classified by their typology and grouping.

\begin{tabular}{|c|c|c|c|c|}
\hline Structure & Session/Topic & Individual Activities & Small Group Activities & Class Group Activities \\
\hline Exploring & Exploratory session & $\begin{array}{l}\text { 1. Exploring previous FW } \\
\text { knowledge }\end{array}$ & - & - \\
\hline \multirow[b]{2}{*}{ Intervention } & $\begin{array}{l}\text { Sessions } 1 \text { and } 2 . \mathrm{FW} \\
\text { concept and social } \\
\text { consequences }\end{array}$ & $\begin{array}{l}\text { 2. Describing feelings } \\
\text { associated with images } \\
\text { showing FW and unequal } \\
\text { food distributions } \\
\text { 4. Defining FW }\end{array}$ & $\begin{array}{l}\text { 5. Dynamics "The } \\
\text { unsupportive lunch": } \\
\text { modelling unequal food } \\
\text { distribution worldwide by } \\
\text { distributing different amounts } \\
\text { of food to pupils. Group } \\
\text { reflection }\end{array}$ & $\begin{array}{l}\text { 3. Sharing feelings when } \\
\text { looking at images and } \\
\text { reflecting } \\
6 \text {. Sample of the data obtained } \\
\text { from measuring FW in the } \\
\text { school canteen, calculation of } \\
\text { possible rations (the children } \\
\text { who could have eaten them) } \\
\text { and reflecting on the dynamics } \\
\text { "The unsupportive lunch" }\end{array}$ \\
\hline & $\begin{array}{l}\text { Sessions } 3 \text { and } 4 . \\
\text { Environmental impact of } \\
\text { FW and proposals to } \\
\text { reduce it }\end{array}$ & $\begin{array}{l}\text { 7. Exploring previous } \\
\text { knowledge. Does FW } \\
\text { affect the environment? }\end{array}$ & $\begin{array}{l}\text { 8. Dynamics "Water in the } \\
\text { world": Calculating the \% or } \\
\text { volume of water available on } \\
\text { our planet for us to use. Pupils } \\
\text { remove the unavailable } \\
\text { volume of water from a 1-litre } \\
\text { bot-tle filled with water until } \\
\text { they have approximately } 0.25 \\
\text { mL } \\
10 . \text { Proposing measures for } \\
\text { more sustainable food } \\
\text { consumption }\end{array}$ & $\begin{array}{l}\text { 9. Reflecting on the dynamics } \\
\text { "Water in the world" }\end{array}$ \\
\hline \multirow[t]{2}{*}{ Extrapolation } & $\begin{array}{l}\text { Sessions } 5 \text { and } 6 \text {. } \\
\text { Preparing and putting up } \\
\text { posters }\end{array}$ & - & $\begin{array}{l}\text { 11. Discussing the poster's } \\
\text { theme } \\
\text { 12. Preparing posters }\end{array}$ & $\begin{array}{l}\text { 13. Sharing the content of } \\
\text { posters } \\
\text { 14. Putting up posters around } \\
\text { the playground and the school } \\
\text { canteen }\end{array}$ \\
\hline & $\begin{array}{l}\text { Extra session. Awareness } \\
\text { activities during the } \\
\text { mid-morning break }\end{array}$ & - & $\begin{array}{l}\text { 15. Informing the school's } \\
\text { other pupils about the FW } \\
\text { problem and how to reduce it }\end{array}$ & - \\
\hline Synthesis & Evaluative session & $\begin{array}{l}\text { 16. Exploring the acquired } \\
\text { FW knowledge }\end{array}$ & - & - \\
\hline
\end{tabular}

The didactic sequence was divided into four parts: the first, prior to the intervention, aimed to explore their previous ideas about FW through a previous questionnaire (Tables 1 and 2). The second part (intervention) was for introducing and looking in-depth at the FW concept and problem. This second part comprised four sessions: knowledge of the problem; its social and environmental consequences; and measures proposed to reduce it. In order to involve pupils and to facilitate understanding the problem, images and activities related to their immediate surroundings were used. To this end, graphic material was developed and combined with practical and manipulative activities to show the volume of food wasted in the school canteen and during meals. Pupils were also encouraged to reflect on the injustice of one part of the population not being able to cover their basic nutritional needs, while another part can afford to throw their leftover food away. For this purpose, the number of children who could have eaten the amount of food thrown away in the canteen was calculated. The greenhouse effect, climate change and water footprint concepts were also worked on, along with their relation to food production, distribution, purchase and waste. They were also taught how to interpret food labelling, and to differentiate between the meaning of the expiry and best before dates on food labels. In addition, simple day-to-day actions that pupils can perform to achieve a more sustainable diet were compiled and proposed using an information brochure prepared from a document published by the FAO as material to support this task. This brochure forms part of the global initiative to reduce food loss and FW: Do good, save food [44].

In the third part of the educational sequence (extrapolation), pupils became drivers of change by performing a series of activities to raise their schoolmates' awareness and 
to disseminate actions that end up generalizing more responsible food consumption. To do this, two sessions were held to produce informational posters to be placed in different places of the school and in the school canteen. The poster presentation took place during the mid-morning break when the intervention group was in charge of informing their schoolmates from other courses about the problem by explaining what they had learned in class and using the posters they had made as a claim. Thus, learning curricular contents were combined during the same intervention with providing society a service by raising community awareness about the FW problem in order to reduce it. Explanations were recorded for later transcription and analysis purposes.

Finally, the fourth part of the sequence was used for synthesis or evaluation, during which the same items as in the previous questionnaire were asked again to observe any possible changes.

A brochure was prepared for teachers, which included a first part to provide information on the scope and impact of FW with global and national data. A second part listed examples of possible teaching activities to work on this issue in the classroom, together with a justification for its inclusion based on different sources. The aim was to achieve a more positive attitude towards incorporating FW into their teaching.

\subsection{Food Waste Collection}

FAO [1] distinguishes between food loss and FW by identifying the latter as the food losses that occur at the end of the food chain; i.e., retail and final consumption. In this study, FW is understood as all foods that, despite preserving their nutritional value and meeting safety standards, are removed from the food chain [45]. FW was quantified during the mid-morning break and lunch. All the pupils $(n=250)$ had a snack during the mid-morning break (from 11:15 h to 11:45 h) and around 150 pupils aged from 3 to 6 years (Pre-Nursery and Nursery) $(\mathrm{n}=48)$ and from 6 to 12 years (Primary Education) $(\mathrm{n}=100)$ stayed for lunch (from 14:00 h to 15:30 h), which is organized in three successive shifts.

The mid-morning break snack is prepared at home and eaten in the playground. Leftovers were placed in the bins in this area. To estimate the FW generated during the mid-morning breaks before and after the intervention, the waste from the intervention group was weighed separately from the rest of the school group, except for the Pre-Nursery and Nursery classes, in which this measure was not taken because leftovers are returned to parents. Waste measurement was carried out on 5 consecutive school days, and both before and after the intervention. By counting only edible parts, it was weighed on a digital scale (For US, model BT-32013).

For lunch, the school had its own kitchen where the menu is cooked, prepared by a nutritionist and managed by a catering company. There is only one menu that is served on trays, except for special diets (allergies, halal, vegetarian). Pupils can have second helpings if they wish. Supervision during meals is carried out by monitors, and each class had its own. The school canteen is a room that is equipped for this very purpose, with no noise dampening system or background music. The food left both on plates and in the kitchen was placed in a conventional waste container. Organic waste and inorganic waste were not separated.

In the school canteen, only the leftovers on plates, understood as the quantity of edible food served and not eaten [46], were quantified because this represents the largest source of FW in schools $[18,25]$. Following the guidelines of the pilot study conducted by the Spanish Ministry of Agriculture, Fisheries and Food [47], measurements were taken on 5 consecutive school days, before and after the intervention, to include diverse dishes and to, thus, minimize the impact of their greater or lesser acceptance by diners. During both periods however, the menu was similar.

The quantification of the FW generated during lunch was carried out by the selective aggregate weighing method in order to simplify and accelerate data collection, when the total generated FW was weighed by differentiating food types. Then the average was calculated for each diner. The weighing method is considered the most precise method 
for quantifying FW compared to others, such as visual estimations, estimations with digital photographs or self-assessments using questionnaires [24,48-51]. The protocol for measuring FW on plates was defined by adapting the protocols described in previous works $[47,48,52]$, and consisted in weighing three random portions of each menu component and taking their average as the weight of served portions. For weighing purposes, the same digital scale used for measuring mid-morning breaks was employed. The total amount of served food was calculated by multiplying the average weight of each portion by the number of diners every day.

Three waste collection areas were set up and four bins were placed in them, one for each food group, apart from the usual container for non-organic waste. During meals, direct observation took place to ensure that pupils did not throw food on the floor or dispose of food on their own. The leftovers on each tray were separated by two previously trained research collaborators, who classified them into: first course, second course (including salad), bread and dessert, following the methodology of Boschini et al. [48] and Sánchez [53]. Drinks were not included as only water was served. Menus were not differentiated from special diets because there were only a few special diets. Data were collected by differentiating among Pre-Nursery and Nursery, Primary and the intervention group using different bins for all the groups. The collected bags were weighed separately on a digital scale with a wider weighing range (Cozzine, model no. FG830LB). In order to calculate the amount of edible FW, the proportional part of non-usable remains, such as bones, skin or fruit cores, if any, was removed. For this purpose, three samples of non-edible parts were weighed, and the proportional part of the total collected weight was averaged and subtracted according to Byker et al. [54]. The FW on plates was expressed as grams and percentages using the following formula: (amount of edible food thrown away/amount of edible food served) $\times 100$. As biases are associated with fruit quantification, the results did not include the FW from desserts.

\subsection{Data Analysis}

The intervention impact was measured using the pre-post knowledge, attitudes and behaviors pertaining to FW, as well as considering FW measurements. Questionnaire data, children's drawings and posters, and transcribed verbatim were categorized, coded and analyzed by thematic analyses. With drawings, a multimodal content analysis was carried out by studying both the images and text accompanying them $[55,56]$ and categorizing FW issues. In relation to the FW quantification, the FW generated during the mid-morning break and on trays after the lunch (post-consumption) was weighed before and after the didactic intervention; in both cases, the mean and standard deviation of these measurements were calculated, separating the values according to the different school groups, when possible. The FW percentage was calculated, dividing the amount of edible food thrown away by the amount of edible food served and multiplying the result by 100 .

\section{Results}

3.1. Pupils

\subsubsection{The FW Concept and Attitudes Towards It}

The analysis of the questionnaires completed by the pupils who did both the preand post-intervention questionnaires $(n=10)$ reveals that when they were asked: What do you mean by FW?, seven out of ten pupils incorporated new items or changed those they had initially included. Most of the group identified the FW concept with terms like throwing away, wasting or wasting food before and after the intervention. After the intervention however, some responses also included other elements, such as the social dimension ("Throwing away food that others don't have"), the idea of it being an avoidable phenomenon ("Not wanting food, throwing it away and not keeping it", "Throwing away food instead of keeping it"), its environmental impact ("Throwing away food is not good for the environment") and some causes of waste ("They throw away food without having used it or when it expires", "Food that is not consumed", "Food that spoils"). These 
changes were more evident when analyzing the drawings which they used to represent FW. The studied categories are shown in Table 3.

Table 3. Categories used for analyzing pupils' drawings.

Presence of the Following Elements in Drawings

- Only bin with food: drawing showing no personal connection with the problem, with the act of throwing food away

- $\quad$ People throwing food away: attributes towards the act of throwing food away for the individual, and not the action of others

- Environmental issues related to climate change, use of natural resources

- Social issues related to unequal access to food

- Allusion to measures to reduce FW. For example: posters with awareness activities, messages with recommendations

- $\quad$ Data about FW levels (figures, percentages, etc.)

- Manifestation of sadness, empathy with the problem

Before the intervention, most drawings showed food thrown away as rubbish. After the intervention however, the FW concept had broadened, with drawings including desirable and undesirable food consumption actions, data (numerical information) about the scope of the problem, the environmental impact associated with it, and the social dimension by reflecting unequal access to food worldwide. They also drew people who were sympathetic to the problem. The only category in which the provided information reduced was for the drawings of people throwing food away, which were replaced with other drawings, a fact that can be interpreted as not wanting to appear as a part of the problem. Two examples of such are found in Figure 2.

In relation to attitude, when asked: Do you ever throw away part of the snack you bring from home?, nine out of ten of the pupils in the intervention group said that they never threw away any of their snacks, a fact that was verified by the amount of food collected during the mid-morning break. There was only one pupil who responded that (s)he sometimes threw away his/her snack because the ration was too big. However, after the intervention, all pupils stated that they never threw food away, nine because they ate it all and one because they kept leftovers to take home. These data suggest a change in attitude because the pupil who stated occasionally throwing away food that (s)he did not want before the intervention, stated they kept for later after the intervention.

In response to the question "Do you ever throw away some of the food you are served at lunch?", most of the pupils admitted throwing food away every day or sometimes, and both before and after the intervention. After the intervention however, the number of pupils who stated never throwing away food increased from three to five out of ten. Regarding the questions "Are you worried about throwing food away?" And "why?", before the intervention all the pupils reported that throwing food away worried them. After the intervention, two out of ten said they did not worry, and alleged that they did not throw food away. 


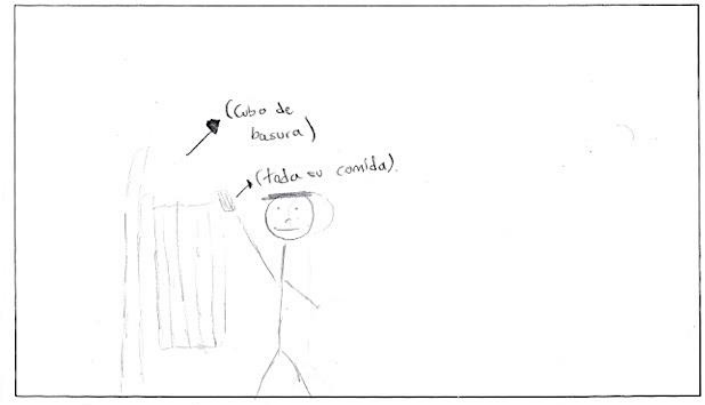

(a)

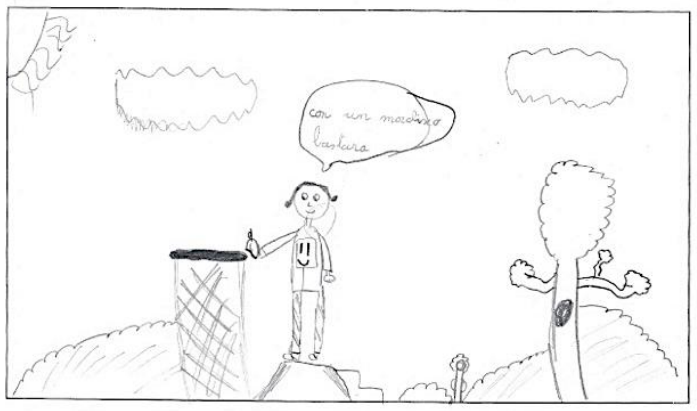

(c)

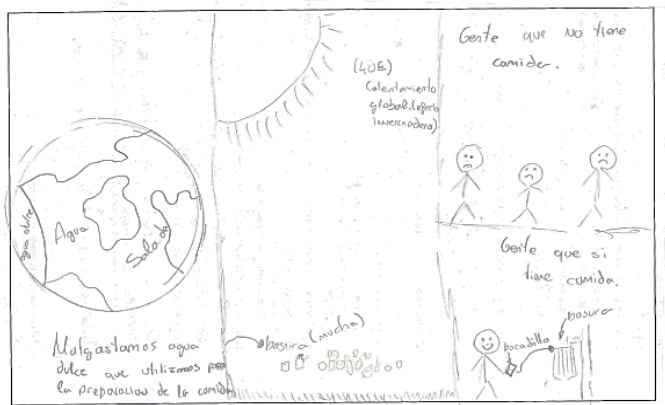

(b)

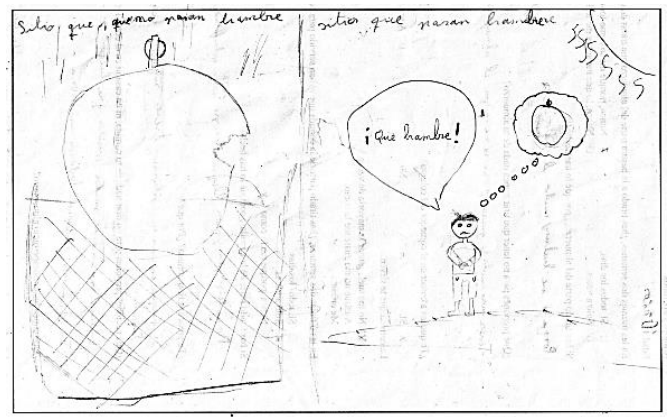

(d)

Figure 2. Drawings by year-4 pupils when they were asked to draw what FW was. Drawings (a) and (c) correspond to those drawn before the intervention, and (b) and (d) after the intervention.

\subsubsection{Classroom Intervention}

The analysis of the posters produced by pupils showed different ideas that had been worked on during the classroom intervention; for example, the posters depicted some causes like the strict aesthetic standards on fruit and vegetable sales, or consequences like the socio-environmental impact of FW, or they showed actions to reduce FW being performed. It should be noted that, although these changes were not clearly perceived in the questionnaires, the group's intervention showed a remarkable change during the information session held in the playground. Some of the comments made by pupils were: "To grow crops that people don't need later, they cut down trees and they take the environment away from animals", "To take food from crops to supermarkets, they use lorries, which make smoke that also pollutes. Also, in supermarkets they put food in packs and people may buy one pack for one person, but cannot eat it all. So they waste food", "Food can be reused, for example, you can make an apple pie with apples. With leftover stew, you can make 'ropa vieja' (name of a dish)" instead of throwing it away, "We cannot change the way food arrives at supermarkets. What we have to avoid is throwing food away because if we do, here you see that (points to a sign) if we throw away an apple, 70 litres of water are wasted, so we lose lots of resources", "We must not eat expired food. What we must try to do is to avoid it expiring by buying too much food".

Some proactive attitudes of the pupils who participated in the intervention were detected. For example, after one of the mid-morning breaks, they mentioned that one child was about to throw away part of his/her lunch after being told not to, but to keep it to eat later. During a trip, they asked to photograph the large amount of food found in the bin so they could include it in their posters.

Finally, all the families that answered the survey to find out if pupils had presented the FW at home $(\mathrm{n}=10)$ stated that their children had.

\subsubsection{Food Waste Collection}

The intervention group hardly generated any FW during the mid-morning breaks before or after the intervention, which confirmed the answers in the questionnaire. In relation to the 
other Primary school pupils, a decrease of almost half of the average weight of the FW in $\mathrm{kg}$ per day was observed after the intervention $(0.895 \pm 0.130 \mathrm{~kg}$ and $0.463 \pm 0.244 \mathrm{~kg}$ per day, before and after the intervention respectively; mean \pm standard deviation).

The total number of meals served in the school canteen during the study was 1488: 785 before the intervention and 703 after. The results of the FW generated on trays (post-consumption) during lunch are shown in Table 4 , expressed as both grams and as a \% of the total grams served on plates (percentage calculated as the amount of edible food thrown away divided by the amount of edible food served, with the result multiplied by 100), because weight varies depending on the food type and the way it is cooked. Generally speaking, before the intervention the average FW on plates was $140 \pm 23 \mathrm{~g}$ per pupil per day, which represents $37.54 \%$ of the weight of served food. It lowered after the intervention to $111 \pm 27 \mathrm{~g}$ per pupil, $36.63 \%$ in relation to served food. When analyzing the FW on plates in the different groups, the percentage of waste increased from $23.30 \%$ to $26.48 \%$ after the intervention in the Preand Nursery groups. In Primary Education, around 30\% FW reduction was achieved in the intervention group, compared to that taken as a reference before the intervention. In terms of percentage, no reduction was observed in the rest of the Primary School. The amount of FW on the intervention group was $177 \pm 23 \mathrm{~g}$ per person and day to $101 \pm 33 \mathrm{~g}$ per person and day before and after the intervention.

Table 4. Average FW quantification in grams (mean \pm standard deviation) and \% during lunch in the Pre-Nursery, Nursery and Primary Education years.

\begin{tabular}{|c|c|c|c|c|c|c|c|c|}
\hline \multirow{4}{*}{ Period } & \multirow{4}{*}{$\begin{array}{l}\text { Waste on Plates per } \\
\text { Pupil per Day }(g)\end{array}$} & \multirow{4}{*}{$\%$ FW } & \multicolumn{6}{|c|}{ Food Waste on Plates per Groups } \\
\hline & & & \multirow{2}{*}{\multicolumn{2}{|c|}{ Pre-Nursery and Nursery }} & \multicolumn{4}{|c|}{ Primary } \\
\hline & & & & & \multicolumn{2}{|c|}{$\begin{array}{c}\text { Primary, Except Intervention } \\
\text { Group }\end{array}$} & \multicolumn{2}{|c|}{ Intervention Group } \\
\hline & & & g & $\%$ & g & $\%$ & g & $\%$ \\
\hline Pre-intervention (1) & $140 \pm 23$ & 37.54 & $87 \pm 23$ & 23.30 & $164 \pm 27$ & 43.76 & $177 \pm 23$ & 47.83 \\
\hline Post-intervention (2) & $111 \pm 27$ & 36.63 & $81 \pm 24$ & 26.48 & $130 \pm 29$ & 42.85 & $101 \pm 33$ & 32.95 \\
\hline
\end{tabular}

(1) No. of food items served: 785; Average weight of total portion served: $375 \mathrm{~g}$. (2) No. of food items served: 703; Average weight of total portion served: $280 \mathrm{~g}$.

\subsection{Teachers}

The FW Concept and Attitudes Towards It

Of the 17 schoolteachers, nine answered the questionnaire in the pre-intervention phase and 15 in the post-intervention phase. The definition of FW provided by the comparable teacher sample before the intervention was related to the terms purchase management, household organization and food expiry. Some examples are "Poor management in both the purchase and organization of food at home, which results in throwing a lot of food away", "Food leftovers are thrown away because they have expired, or are spoilt or left over" and "Buying food in excess and throwing it away when it expires or no longer looks perfect (i.e., bananas are a bit dark). Cook more food than necessary and do not eat leftovers, but throw them away". After the intervention, most definitions highlighted the more globalizing concept of throwing food away that is still in good condition for eating. For example, "Food in good condition for eating, but ends up in the rubbish", "FW is that which is thrown away, even if it is in good condition, for several reasons" and "Any food or drink that is thrown away without thinking, even though it is perfect for eating".

As for attitude towards and feelings about the problem, all respondents considered FW to be a problem both before and after the intervention. When considering the comparable sample, seven out of nine teachers initially believed it was an ethical-social problem, one an environmental problem and one an educational problem. After the intervention, the number of the respondents who identified FW as an environmental problem increased to five and one included the economic dimension. However, the level of interest in FW did not change before and after the intervention $(4.11 \pm 1.05$, where 1 is not interested and 5 very interested). 
Of the selection of sustainability-related topics, the issues that teachers addressed most frequently in their classroom were energy and water saving, recycling and the importance of diet. The least addressed ones were product labelling (expiry dates and best before dates), and the environmental impact related to food generation and consumption (Figure 3). Thus the topics most frequently worked on coincided with those that appeared in the official educational curriculum, while those less worked on corresponded to the topics that are more specifically related to FW, a content that does not explicitly appear in the official educational curriculum.

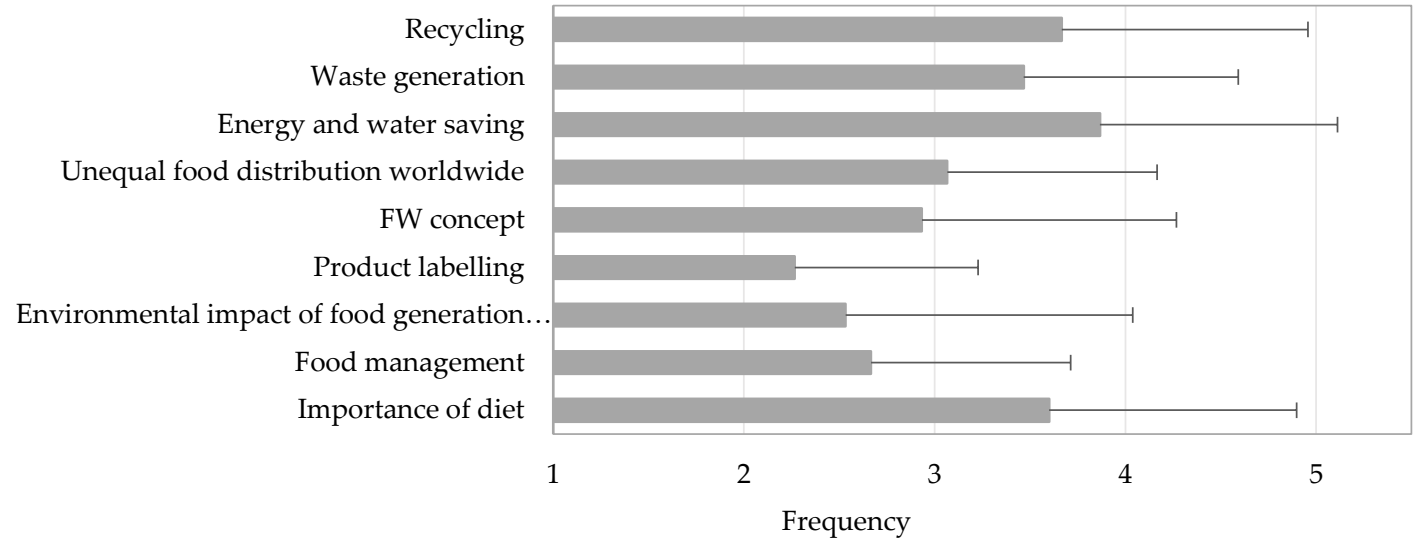

Figure 3. Frequency (expressed as mean scores of each item in columns and standard deviation in bars) with which teachers $(n=15)$ address sustainability issues, being 1 never addressed and 5 very frequently.

After reading the informative leaflet, seven out of 15 surveyed teachers said that they already worked on FW in their classes, and eight stated that they hoped to do so. Table 5 summarizes teachers' proposals following the intervention to address FW in their classrooms.

Table 5. Summary of the activities and contents proposed by teachers to work on FW in class.

\section{Proposed Activities and Contents}

- $\quad$ Provide families with training

- Instill sustainable eating habits during mid-morning breaks by explaining actions to reduce FW

- $\quad$ Propose a project to analyze the amount of food wasted in households, work on graphical data representation, and arrange data in tables, mass units

- Run a debate on the subject from the English subject to practice oral communication and food-related vocabulary

- $\quad$ Run a game in which different foods with various expiry dates are drawn and cut out

- Activities to collect food items near their expiry dates or best before dates, and donate them to charity

- $\quad$ Play with different foods and think about how all their parts can be used to generate the least amount of waste

- $\quad$ Compose and perform a song about FW

\section{Discussion}

\subsection{On the Main Issues Addressed in the Study}

Education for Sustainable Development (ESD) is fundamental for providing the knowledge, skills, values, and attitudes needed by people to make conscious decisions and to act responsibly in environmental integrity, economic viability and social justice terms for today's generation and those to come [37]. This work shows that it is not necessary 
to perform main activities to observe changes in students' knowledge, awareness and behavior, which was proven in relation to FW. Moreover, it is precisely at early ages when this education is likely to bring about a change and turn youngsters into drivers of change. Focusing on Secondary and Higher Education levels may be too late to integrate this attitude into their way of being.

The scientific literature shows different strategies to reduce FW in the education environment, and its scope in the collective catering sector, and the most elaborate or sophisticated ones do not always offer the most satisfactory results [29-31]. Goldberg et al. [23] carried out a comprehensive information campaign with pupils (year 3 and 4 ) and families (involving up to 82 classes from 12 schools) to promote eating fruit and vegetables and to reduce waste. These authors did not achieve any change in student behavior, which they attributed to complex information transfer because campaign messages would have to be presented to children by teachers, who would have to be motivated to explain what they learned to their parents, who would have to be persuaded by their children or by the material provided to buy healthy food. Bustamente et al. [24] involved students in quantifying the FW generated on plates both before and after implementing awareness activities at Spanish schools in different regions, in which teachers, students and canteen staff participated. The campaign obtained a statistically significant $20.7 \%$ reduction in FW on plates, but only in schools in central Spain. Ozcicek-Dolekoglu and Var [26] carried out an awareness campaign in the canteen of a Turkish university by placing informative posters with obtained FW data in the same canteen, but were unable to reduce waste by students, only among the faculty and administrative staff, albeit not statistically and significantly. After an education campaign by placing informative posters in strategic areas of a canteen at a Portuguese University, Soares et al. [27] managed to bring about changes in behavior by detecting reduced FW after raising student awareness. Engström and Carlsson-Kanyama [25] also observed a 35\% reduction in FW on plates after involving teachers and students from two Swedish schools in weighing the waste generated in the center.

In our case study, a didactic intervention to inform and involve students in reducing FW achieved a reduction of up to $30 \%$ in the intervention group by cutting the amount of FW from $177 \pm 23 \mathrm{~g}$ per person and day to $101 \pm 33 \mathrm{~g}$ per person and day, but no reduction in the percentage was observed for the rest of the Primary Group. FW reduction in grams per day was more striking for the mid-morning break because, in that context, the intervention group not only showed, but also explained, the informative posters to their schoolmates, unlike the school canteen, where only posters were placed. In addition, students' margin of action with the mid-morning break snack was wider because they could ask families for smaller rations, choose what to eat to a certain extent, and keep the food they did not eat for later. They could not carry out all these measures in the school canteen. Therefore, it would seem that only placing persuasive posters is not enough to bring about a change in student attitudes, but direct actions with groups are necessary. These conclusions coincide with those identified in other works $[23,25,26,53]$. The Pre- and Nursery groups were the most impervious to all the performed actions. It should be noted that these pupils were unable to read the posters in the playground and the school canteen. As they did not share the playground with Primary School pupils, they did not receive oral information during the awareness session from the intervention group. Even though this is a small-scale work with a specific didactic intervention applied to a classroom, it helped to verify the advantages of cascade learning because the group with which it was carried out actively participated in raising the awareness of the other pupils at school, which can have a positive and stronger effect than when an adult transmits information.

When focusing on FW quantification on plates, an average daily waste of $140 \pm 23 \mathrm{~g}$ per pupil was recorded before the intervention, which represents $37.54 \%$ of FW vs. served food. The results in grams are higher than those obtained in previous works $[24,47,48,50]$, especially before the intervention, but are similar to those obtained by Bergman et al. [57] with students who spent the same time eating as the students in our work, and less time 
than those obtained by Boschini et al. [58] at Primary School. However, these results depend largely on the food type served every day as some preparations have a bigger mass than others. The results obtained as percentages are also higher than those obtained in other studies carried out in schools [50,59], revealing truly high figures of FW, especially considering that our study did not include the waste produced in desserts, which incurs a very high waste level, especially if fruit is included, and further rises if fruit needs peeling [23]. When comparing the waste levels of the different groups (Pre- and Nursery, and all Primary Education), the data revealed that the Pre- and Nursery groups generated the least waste, which coincides with Derqui and Fernández [22]. This may be because monitors are more aware about them eating everything. For the degree of acceptance of menus, the data revealed that the food most rejected by students included legumes, fish and vegetables. These results agree with those obtained in other studies $[19,60,61]$.

When analyzing the effects of the intervention in relation to the level of knowledge and attitude in the intervention group and teachers, changes were detected in pupils which, although they were not clearly reflected in the questionnaires, came over during the dissemination session when they had to raise the awareness of the rest of the school, and also in some drawings. Drawings are affected by the ability to draw, but also by children's age and cognitive development [62]. Although we detected a change before and after the intervention in the content of drawings, we expected them to be able to better convey knowledge about FW, as shown during exhibitions. As stated by Grieve and Hughes [63], "Children often know more than their drawings reveal". Furthermore, the fact that $100 \%$ pupils whose families were surveyed mentioned at home what they were working on in class revealed that their interest had been aroused and they wished to share it with their families.

The changes noted for teachers were much subtler. It is striking that the intervention was not related to an increased interest in the problem, which was based on a medium high level of interest ( 4 out of 5 according to a Likert scale). However, eight out of 15 of the teachers expressed being interested in incorporating the issue into their classes, especially after learning about examples of activities and initiatives to address FW in the classroom. In order to bring about more significant changes in these groups, it would be advisable to act directly on them by increasing their level of information and their awareness about FW. It might also be useful for teachers to disseminate the initiatives carried out in other schools to inspire them, such those promoted by the International Food Waste Coalition [21].

\subsection{Limitations and Further Research}

The present paper focuses on a case study, and the constraints that arise from it must always be taken into account.

Firstly, our sample was small and located in a single center, which does not make our results generalizable. However, it is not always possible to extend the intervention to several classrooms or to a large number of students that would, in principle, be desirable. It would depend on the number of teachers who can carry out the intervention in different classrooms, who must already have trained knowledge and skills as to how to work with the FW problem at school. Even so, promising results can be achieved even if only one teacher works with these dynamics at school. Training this group of students well and allowing them to raise awareness with their peers is per se a good strategy and is, therefore, not seen as a limitation itself.

Secondly, when quantifying the volume of food wasted in the school canteen, we must bear in mind that it can be considerably conditioned by the type of menu. Tastes and appetite levels are extremely individual but, in practice, as schools make huge efforts to adapt their menus to the majority taste, there is not much bias in this regard. What is advisable is to monitor menus over several weeks to cover the different types of food served, which tend to rotate weekly, but also tend to be similar month to month. Ideally, an audit should be carried out on identical menus before and after the intervention to minimize the differences between both measurements. 
We are aware that if we wish to obtain more generalizable data, future works should address a larger sample and propose more intense and lasting didactic interventions in order to enhance their effects, and to encourage acquiring lifelong habits. These studies should also include a more representative sample by taking into account different variables that may influence generated FW, such as the socio-economic level of families, meal times and menu type, among others. Furthermore, future interventions should include the whole education community, as well as families and kitchen and canteen staff, and should involve collaboration with other school-related institutions: markets, food banks, neighborhood shops, among others. Nevertheless, our results may be useful for adopting waste management policies in Primary School canteens, and may be a starting point for future research that focuses on analyzing FW at schools in the Valencian Community (E Spain) because, as far as we know, there are no data available that quantify this FW.

\section{Conclusions}

This work aimed to find out whether different intervention types on several school community members were able to bring about changes in knowledge and attitudes towards FW. The obtained data seem to suggest a change in waste on plates, especially in the group with whom we intervened directly in class, as well as much more knowledge of and awareness about the FW problem shown by our pupils. These changes were subtler for teachers.

Within the current international framework, and given the seriousness of the climate problem which increases every day, it is necessary to encourage these young citizens' involvement in making progress towards sustainable societies by contributing to SDG from all areas. The new global agenda for Sustainable Development 2030 clearly reflects such a vision of the importance of an appropriate educational response. Quality education is both a goal in itself (SDG 4) and a means by which to achieve all other SDGs because it is an integral part of sustainable development and a key enabler. This is why education represents an essential strategy in achieving SDGs [37]. This makes apparent the importance of proposals like those herein presented to achieve the other goals set by Agenda 2030 by working on FW, in school canteens in our case, which is one of the most global problems with the most cross-cutting impacts that humanity must solve. The educational intervention of this study showed that, by working on FW, it contributes to achieve not only SDG 4 and SDG 12, which it is directly related to but, from education, it also allows other Agenda 2030 goals to be worked on. In practice, we observed that by addressing the FW theme in classrooms with different activities (Table 2), we contribute to achieve the 2030 Agenda as a whole, especially certain aspects, as shown in Figure 4: climate change, inequalities, hunger, poverty and life in more equitable and sustainable cities. In this way, this work aims to inspire teachers and centers to incorporate FW into their teaching programs in order to raise awareness about the amount of SDG and skills that can be worked on in relation to this issue. 


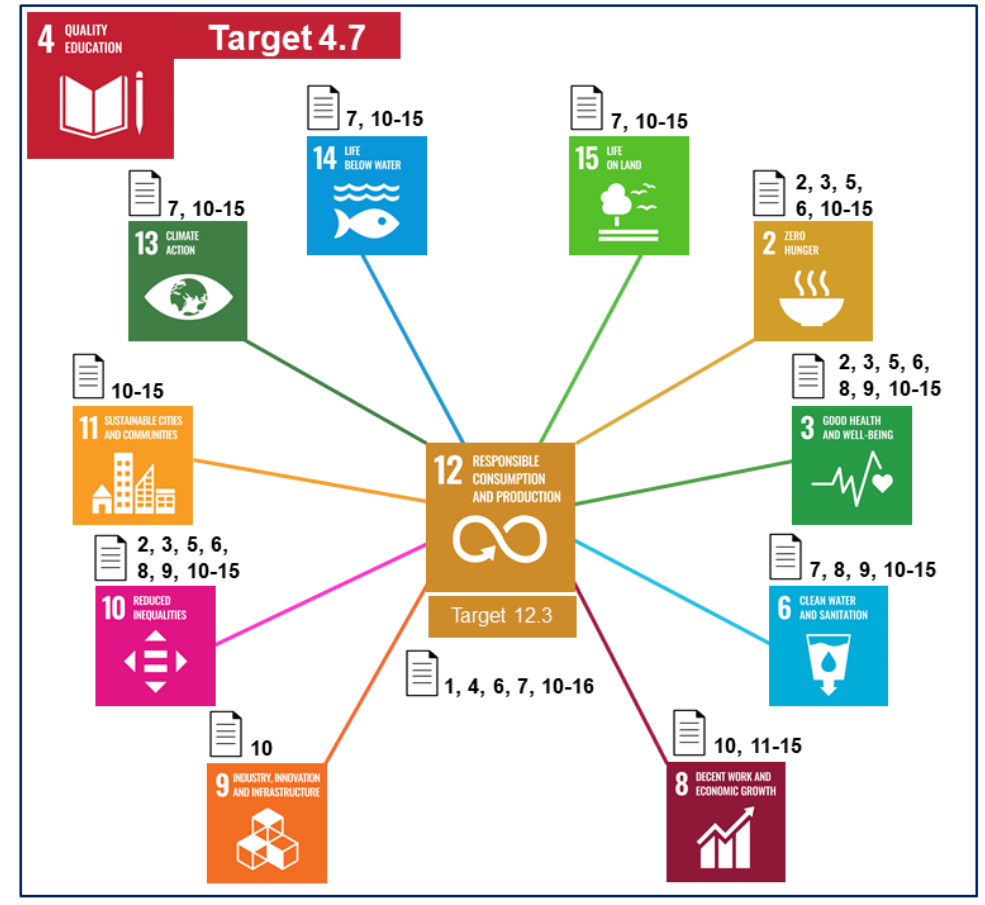

Figure 4. Sustainable development objectives addressed in the educational intervention when working on FW from the educational field by informing and involving students in reducing FW. The numbers of activities in the different SDGs refer to the activities indicated in Table 2. Source: designed by the authors using images from un.org.

Author Contributions: Conceptualization, A.A.-P., M.-A.F.-Z. \& T.P.; methodology, A.A.-P., M.-A.F.Z. \& T.P.; formal analysis, A.A.-P. \& T.P.; resources, A.A.-P.; writing-original draft preparation, A.A.-P. \& T.P.; writing-review and editing, A.A.-P., M.-A.F.-Z. \& T.P.; supervision, M.-A.F.-Z. \& T.P. All authors have read and agreed to the published version of the manuscript.

Funding: This research received no external funding.

Informed Consent Statement: Informed consent was obtained from all subjects involved in the study.

Acknowledgments: The results of the present study form part of the contract "Análisis de las necesidades docentes sobre el desperdicio alimentario en CEIPs de la Comunidad Valenciana: diseño de propuestas didácticas y opciones de implementación desde el marco de la Didáctica de las Ciencias Experimentales. CPI-20-473" and are included in the plan against food waste in the Comunitat Valenciana (BonProfit Plan), financed by the General CAP Agency (Conselleria de Agricultura, Desarrollo Rural, Emergencia Climática y Transición Ecológica, of the Generalitat Valenciana). The authors wish to thank to the Valencian school, their teachers and their pupils that participate in the study.

Conflicts of Interest: The authors declare no conflict of interest.

\section{References}

1. United Nations Transforming Our World: The 2030 Agenda for Sustainable Development. 2015. Available online: https: //www.un.org/ga/search/view_doc.asp?symbol=A/RES/70/1\&Lang=E (accessed on 15 November 2020).

2. Lipinski, B.; Clowes, A.; Goodwin, L.; Hanson, C.; Swannell, R.; Mitchell, P. SDG TARGET 12.3 on Food Loss and Waste: 2017 Progress Report Executive Summary; World Resources Institute: Washington, DC, USA, 2017; Available online: https: / www.wrap.org.uk/sites/ files/wrap/Target\%2012.3_2017\%20Progress\%20Report_FINAL.pdf (accessed on 15 November 2020).

3. FAO. Global Food Losses and Food Waste. Extent, Causes and Prevention; FAO: Rome, Italy, 2011; Available online: http://www.fao. org /3/mb060e/mb060e.pdf (accessed on 15 November 2020). 
4. $\quad$ Bio Intelligence Service. Preparatory Study on Food Waste Across Eu 27; Technical Report 054. 2010; European Communities: Brussels, Belgium, 2011; Available online: https:/ / ec.europa.eu/environment/eussd/pdf/bio_foodwaste_report.pdf (accessed on 15 November 2020).

5. $\quad$ Stenmarck, Å.; Jensen, C.; Quested, T.; Moates, G.; Cseh, B.; Juul, S.; Parry, A.; Politano, A.; Redlingshofer, B.; Scherhaufer, S.; et al. FUSIONS-Estimates of European Food Waste Levels. IVL-Report C 186; IVL Swedish Environmental Research Institute: Stockholm, Sweden, 2016; Available online: https:/ / www.eu-fusions.org/phocadownload/Publications/Estimates\%20of\%20European \%20 food\%20waste\%20levels.pdf (accessed on 15 November 2020).

6. FAO. Food Wastage Footprint: Impacts on Natural Resources-Summary Report; FAO: Rome, Italy, 2013; Available online: http: //www.fao.org/3/i3347e/i3347e.pdf (accessed on 15 November 2020).

7. Béné, C. Resilience of local food systems and links to food security-A review of some important concepts in the context of COVID-19 and other shocks. Food Secur. 2020, 12, 805-822. [CrossRef] [PubMed]

8. Lal, R. Home gardening and urban agriculture for advancing food and nutritional security in response to the COVID-19 pandemic. Food Secur. 2020, 12, 871-876. [CrossRef] [PubMed]

9. Niles, M.; Bertmann, F.; Belarmino, E.; Wentworth, T.; Biehl, E.; Neff, R. The Early Food Insecurity Impacts of COVID-19. Nutrients 2020, 12, 2096. [CrossRef] [PubMed]

10. FAO; IFAD; UNICEF; WFP; WHO. The State of Food Security and Nutrition in the World 2020. Transforming Food Systems for Affordable Healthy Diets; FAO: Rome, Italy, 2020. [CrossRef]

11. Aldaco, R.; Hoehn, D.; Laso, J.; Margallo, M.; Ruiz-Salmón, J.; Cristobal, J.; Kahhat, R.; Villanueva-Rey, P.; Bala, A.; Batlle-Bayer, L.; et al. Food waste management during the COVID-19 outbreak: A holistic climate, economic and nutritional approach. Sci. Total Environ. 2020, 742. [CrossRef]

12. Batlle-Bayer, L.; Aldaco, R.; Bala, A.; Puig, R.; Laso, J.; Margallo, M.; Vázquez-Rowe, I.; Antó, J.M.; Fullana-i-Palmer, P. Environmental and nutritional impacts of dietary changes in Spain during the COVID-19 lockdown. Sci. Total Environ. 2020, 748. [CrossRef]

13. MAGRAMA. Spanish Strategy "More Food, Less Waste". Program to Reduce Food Los and Waste and Maximise the Value of Discarded Food; Ministerio de Agricultura, Alimentación y Medio Ambiente: Madrid, Spain, 2013. Available online: https:/ / menosdesperdicio. es/sites/default/files/documentos/relacionados/spanish_strategy_more_food_less_waste.pdf (accessed on 15 November 2020).

14. Derqui, B.; Grimaldi, D.; Fernandez, V. Building and managing sustainable schools: The case of food waste. J. Clean. Prod. 2020, 243. [CrossRef]

15. Elkington, J.; Tickell, S.; Lee, M. SustainAbility. In 20 Years of Global Leadership; SustainAbility: London, UK, 2007.

16. Parfitt, J.; Barthel, M.; Macnaughton, S. Food waste within food supply chains: Quantification and potential for change to 2050. Philos. Trans. Royal Soc. B Biol. Sci. 2010, 365, 3065-3081. [CrossRef]

17. Díaz, R. Som Conscients del Malbaratament Alimentari que Generem? Percepció Social i Proposta de Mesura, Barcelona. Master's Thesis, Universitat Politècnica de Catalunya, Barcelona, Spain, 2013.

18. Eriksson, M.; Persson Osowski, C.; Malefors, C.; Björkman, J.; Eriksson, E. Quantification of food waste in public catering services-A case study from a Swedish municipality. Waste Manag. 2017, 61, 415-422. [CrossRef]

19. Cordingley, F.; Reeve, S.; Stephenson, J. Food Waste in Schools. Summary Report; Waste \& Resources Action Programme: Banbury, Oxon, UK, 2011; Available online: https:/ / www.wrap.org.uk/sites/files/wrap/Food\%20Waste\%20in\%20Schools\%20Summary\% 20Report.pdf (accessed on 15 November 2020).

20. Quested, T.E.; Marsh, E.; Stunell, D.; Parry, A.D. Spaghetti soup: The complex world of food waste behaviours. Resour. Conserv. Recycl. 2013, 79, 43-51. [CrossRef]

21. International Food Waste Coalition (IFWC). SKOOL 2018 Report SKOOL PILOT Working Together for Schools and Food Services without Food Waste. Do Good: Save Food! School Kitchen Organisation Optimisation Learning; International Food Waste Coalition: Ixelles, Belgique, 2018.

22. Derqui, B.; Fernandez, V. The opportunity of tracking food waste in school canteens: Guidelines for self-assessment. Waste Manag. 2017, 69, 431-444. [CrossRef]

23. Goldberg, J.P.; Folta, S.C.; Eliasziw, M.; Koch-Weser, S.; Economos, C.D.; Hubbard, K.L.; Tanskey, L.A.; Wright, C.M.; Must, A. Great Taste, Less Waste: A cluster-randomized trial using a communications campaign to improve the quality of foods brought from home to school by elementary school children. Prev. Med. 2015, 74, 103-110. [CrossRef] [PubMed]

24. Bustamente, M.; Afonso, A.; de Los Ríos, I. Exploratory analysis of food waste at plate in school canteens in Spain. Granja 2018, 28, 20-42. [CrossRef]

25. Engström, R.; Carlsson-Kanyama, A. Food losses in food service institutions Examples from Sweden. Food Policy 2004, 29 , 203-213. [CrossRef]

26. Ozcicek-Dolekoglu, C.; Var, I. Analysis of food waste in University dining halls: A case study from Turkey. Fresenius Environ. Bull. 2019, 28, 156-166.

27. Soares, R.; Machado, R.; Fochat, F.; Santos, S.; Masqués-dos-Santos, C.A. A simple awareness campaign to promote food waste reduction in a university canteen. Waste Manag. 2018, 76, 28-38. [CrossRef] 
28. Goonan, S.; Mirosa, M.; Spence, H. Getting a taste for food waste: A mixed methods ethnographic study into hospital food waste before patient consumption conducted at three New Zealand foodservice facilities. J. Acad. Nutr. Diet. 2014, 114, 63-71. [CrossRef]

29. Reynolds, C.; Goucher, L.; Quested, T.; Bromley, S.; Gillick, S.; Wells, V.K.; Evans, D.; Koh, L.; Carlsson Kanyama, A.; Katzeff, C.; et al. Review: Consumption-stage food waste reduction interventions-What works and how to design better interventions. Food Policy 2019, 83, 7-27. [CrossRef]

30. Stöckli, S.; Niklaus, E.; Dorn, M. Call for testing interventions to prevent consumer food waste. Resour. Conserv. Recycl. 2018, 136, 445-462. [CrossRef]

31. Hebrok, M.; Boks, C. Household food waste: Drivers and potential intervention points for design-An extensive review. J. Clean. Prod. 2017, 151, 380-392. [CrossRef]

32. Benvenuti, L.; de Santis, A.; Santesarti, F.; Tocca, L. An optimal plan for food consumption with minimal environmental impact: The case of school lunch menus. J. Clean. Prod. 2016, 129, 704-713. [CrossRef]

33. Boschini, M.; Falasconi, L.; Giordano, C.; Franco, S.; Cicatiello, C.; Marangon, F.; Troiano, S. Preliminary results of a methodology for determining food waste in primary school canteens. Ital. Rev. Agric. Econ. 2017, 72, 303-310. [CrossRef]

34. MAGRAMA. Buen Aprovecho. Guía Práctica para Reducir el Desperdicio de Alimentos en Centros Educativos; Ministerio de Agricultura, Alimentación y Medio Ambiente: Madrid, Spain, 2014.

35. GVA. Decreto 108/2014, de 4 de Julio, del Consell, por el que se Establece el Currículo de Educación Primaria en la Comunitat Valenciana. Available online: https:/ / www.dogv.gva.es/portal/ ficha_disposicion_pc.jsp?sig=006087/2014\&L=1. (accessed on 14 November 2020).

36. BOE. Real Decreto 126/2014, de 28 de Febrero, por el que se Establece el Currículo Básico de la Educación Primaria. Available online: https:/ /www.boe.es/eli/es/rd/2014/02/28/126/dof/spa/pdf. (accessed on 14 November 2020).

37. UNESCO. Education for Sustainable Development Goals: Learning objectives-UNESCO Biblioteca Digital. Available online: https:/ / unesdoc.unesco.org/ark:/48223/pf0000247444 (accessed on 14 November 2020).

38. Vilches, A.; Gil Pérez, D.; Toscano, J.C.; Macías, O. Educación para la Sostenibilidad. Available online: https://www.oei.es/ historico /decada/accion.php?accion=2 (accessed on 14 November 2020).

39. Cohen, L.; Manion, L.; Morrison, K. Research Method in Education, 6th ed.; Routledge: New York, NY, USA, 2007.

40. Stake, R.E. The Art of Case Study Research; Sage: Oaks, CA, USA, 2000.

41. Yin, R.K. Case Study Research and Applications, 6th ed.; Sage Publications: Los Angeles, CA, USA, 2018.

42. Papargyropoulou, E.; Wright, N.; Lozano, R.; Steinberger, J.; Padfield, R.; Ujang, Z. Conceptual framework for the study of food waste generation and prevention in the hospitality sector. Waste Manag. 2016, 49, 326-336. [CrossRef] [PubMed]

43. UNESCO. Rethinking Education. In Towards a Global Common Good? UNESCO: Paris, France, 2015; Available online: https: / / unevoc.unesco.org/e-forum/RethinkingEducation.pdf (accessed on 14 November 2020).

44. FAO. Do Good, Save Food. Nine Easy Tips to Reduce Food Waste. Available online: http://www.fao.org/3/a-i7059e.pdf. (accessed on 14 November 2020).

45. Falasconi, L.; Vittuari, M.; Politano, A.; Segrè, A. Food Waste in School Catering: An Italian Case Study. Sustainability 2015, 7, 14745-14760. [CrossRef]

46. Buzby, J.C.; Guthrie, J.F. Plate Waste in School Nutrition Programs. Final Report to Congress; Economic Research Service/USDA: Washington, DC, USA, 2002.

47. MAGRAMA. Estudio Piloto para la Medición y Reducción del Desperdicio de Alimentos en Comedores Escolares. Diseño de una Auditoría de Autoevaluación; Ministerio de Agricultura, Alimentación y Medio Ambiente: Madrid, Spain, 2016.

48. Boschini, M.; Falasconi, L.; Giordano, C.; Alboni, F. Food waste in school canteens: A reference methodology for large-scale studies. J. Clean. Prod. 2018, 182, 1024-1032. [CrossRef]

49. Hanks, A.S.; Wansink, B.; Just, D.R. Reliability and accuracy of real-time visualization techniques for measuring school cafeteria tray waste: Validating the quarter-waste method. J. Acad. Nutr. Diet. 2014, 114, 470-474. [CrossRef]

50. Liz Martins, M.; Cunha, L.M.; Rodrigues, S.S.P.; Rocha, A. Determination of plate waste in primary school lunches by weighing and visual estimation methods: A validation study. Waste Manag. 2014, 34, 1362-1368. [CrossRef]

51. Liz Martins, M.; Rodrigues, S.S.; Cunha, L.M.; Rocha, A. Strategies to reduce plate waste in primary schools-Experimental evaluation. Public Health Nutr. 2016, 19, 1517-1525. [CrossRef]

52. Hunsberger, M.; McGinnis, P.; Smith, J.; Beamer, B.A.; O'Malley, J. Elementary school children's recess schedule and dietary intake at lunch: A community-based participatory research partnership pilot study. BMC Public Health 2014, 14, 156. [CrossRef]

53. Sánchez, J. Análisis del Desperdicio Alimentario en la Restauración Universitaria: Un Enfoque Experimental. Master's Thesis, Universitat Politècnica de Catalunya, Barcelona, Spain, 2016.

54. Byker, C.J.; Farris, A.R.; Marcenelle, M.; Davis, G.C.; Serrano, E.L. Food Waste in a School Nutrition Program After Implementation of New Lunch Program Guidelines. J. Nutr. Educ. Behav. 2014, 46, 406-411. [CrossRef]

55. Bowker, R. Children's perceptions and learning about tropical rainforests: An analysis of their drawings. Environ. Educ. Res. 2007, 13, 75-96. [CrossRef]

56. López-Megías, L.; Fernández-Castillo, A. Creatividad en la infancia temprana. Análisis cualitativo en un contexto educativo. Reidocrea 2018, 7, 43-54. 
57. Bergman, E.A.; Buergel, N.S.; Englund, T.F.; Femrite, A. The Relationship between the Length of the Lunch Period and Nutrient Consumption in the Elementary School Lunch Setting. J. Child Nutr. Manag. 2004, 28, 1-10.

58. Boschini, M.; Falasconi, L.; Cicatiello, C.; Franco, S. Why the waste? A large-scale study on the causes of food waste at school canteens. J. Clean. Prod. 2020, 246. [CrossRef]

59. Rodríguez-Tadeo, A.; Patiño Villena, B.; Periago Caston, M.J.; Ros Berruezo, G.; González Martínez-Lacuesta, E. Assessing Food Acceptance in schoolar children; qualitative visual record versus food waste analysis. Nutr. Hosp. 2014, 29, 1054-1061. [CrossRef]

60. Aranceta Bartrina, J.; Pérez Rodrigo, C.; Serra Majem, L.; Delgado Rubio, A. Hábitos alimentarios de los alumnos usuarios de comedores escolares en España. Estudio «Dime Cómo Comes». Atención Primaria 2004, 33, 131-139. [CrossRef]

61. Dinis, D.; Marins, M.; Rocha, A. Plate waste as indicator of portion inadequacy at school lunch. World Acad. Sci. Eng. Technol. Int. J. Nutr. Food Eng. 2013, 7, 477-480. [CrossRef]

62. Farokhi, M.; Hashemi, M. The Analysis of Children's Drawings: Social, Emotional, Physical, and Psychological aspects. Procedia Soc. Behav. Sci. 2011, 30, 2219-2224. [CrossRef]

63. Grieve, R.; Hughes, M. An introduction to understanding children. In Understanding Children; Grieve, R., Hughes, M., Eds.; Blackwell Publishers Ltd.: Oxford, UK, 1990; pp. 1-10. 